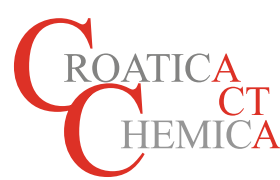

\title{
Synthesis and Anion Binding Assessment of Novel Adamantane Amidopyrroles
}

\author{
Marija Alešković, Mladena Glavaš, Marina Šekutor, Kata Mlinarić-Majerski*
}

\author{
Department of Organic Chemistry and Biochemistry, Ruđer Bošković Institute, Bijenička cesta 54, P.O. Box 180, 10002, Zagreb, Croatia \\ * Corresponding author's e-mail address: majerski@irb.hr \\ RECEIVED: November 27, 2017 * REVISED: March 4, 2018 * ACCEPTED: April 3, 2018
}

THIS PAPER IS DEDICATED TO PROF. MLADEN ŽINIĆ ON THE OCCASION OF HIS 70 ${ }^{\text {TH }}$ BIRTHDAY

\begin{abstract}
Two new adamantane anion receptors with amidopyrrole side arms were prepared and their anion binding ability in DMSO solutions with TBA salts $\left(\mathrm{Cl}^{-}, \mathrm{AcO}^{-}\right.$and $\left.\mathrm{H}_{2} \mathrm{PO}_{4}^{-}\right)$was investigated by UV/Vis spectroscopy. After calculating the corresponding association constants of receptor-anion complexes, it became apparent that only one amidopyrrole side arm was engaged in complexation. These experimental findings were rationalized using computational tools and the binding mode was proposed. In addition to the found $1: 1$ stoichiometry, we showed that the studied receptors bind oxo-anions $\left(\mathrm{H}_{2} \mathrm{PO}_{4}^{-}\right.$and $\left.\mathrm{AcO}^{-}\right)$more strongly than spherical halogenide $\left(\mathrm{Cl}^{-}\right)$anions.
\end{abstract}

Keywords: anion receptors, adamantane amidopyrroles, binding assessment.

\section{INTRODUCTION}

D ESIGN and synthesis of anion receptors has been a very exciting field of supramolecular chemistry in the past thirty years. ${ }^{[1]}$ Numerous studies postulated fundamental principles of anion binding in solution, enabling implementation of anion sensors in interdisciplinary areas of chemistry, biology, medicine and technology. ${ }^{[1]}$ Anion receptor chemistry recently underwent a shift from classical hydrogen bond domain ${ }^{[2]}$ to halogen-bonding[3] and anion- $\pi$ interactions, ${ }^{[4]}$ as well as from binding environment consisting of organic solvents to real-life systems like water. ${ }^{[5]}$ The quest for highly selective receptors ${ }^{[6]}$ also gave rise to their miscellaneous application ${ }^{[7]}$ in self-assembly ${ }^{[8]}$ and molecular architecture, ${ }^{[9]}$ sensing, ${ }^{[10]}$ catalysis, ${ }^{[11]}$ and anion transport. ${ }^{[12]}$

Neutral anion receptors usually incorporate moieties such as amine,[13] amide, ${ }^{[14]}$ (thio)urea, ${ }^{[15]}$ pyrrole, ${ }^{[16]}$ etc., whereas many receptors combine more than one functional group to effectively bind anions by taking advantage of hydrogen bond formation. ${ }^{[1,6]}$ Pyrrole as an anion binding unit is often incorporated into receptor molecules because of its acidic $\mathrm{NH}$ hydrogen that is rather stable in a wide $\mathrm{pH}$ range. Moreover, pyrroles are easily substituted with additional hydrogen bond donating groups, such as amide ${ }^{[17,18]}$ or guanidinium, ${ }^{[19]}$ and can be incorporated in various cyclic and acyclic motifs, thus building a library of compounds potent in complexing anions with higher selectivity and affinity. One such substituted pyrrole motif much exploited in the work of Gale ${ }^{[18]}$ is amidopyrrole, a system consisting of two joined, potent binding sites.

Our research group investigated synthesis and anion binding properties of pyrrole, ${ }^{[20]}$ urea $^{[21]}$ and guanidine ${ }^{[22]}$ receptors that contained adamantane as a polycyclic unit in the structure. We hypothesized that incorporation of a rigid and bulky adamantane moiety between the symmetrical binding sites would diminish rotational mobility of the sensor and in that way somewhat preorganize it for anion trapping. We showed that even simple systems with two pyrroles can bind anions effectively (like acyclic dipyrromethanes), ${ }^{[20 a, c]}$ while solubility issues for cyclic systems prevented a more detailed examination of their anion binding properties.[20b] Preliminary positive results prompted us to introduce a phenyl chromophore group into the binding region of dipyrromethane systems in order to develop new colorimetric or fluorescent anion sensors. Introduction of aromatics with different electronwithdrawing and electron-donating groups later on would allow us to vary the anion selectivity in the sensor series and further explore their efficiency. ${ }^{[20 \mathrm{~d}]}$ 

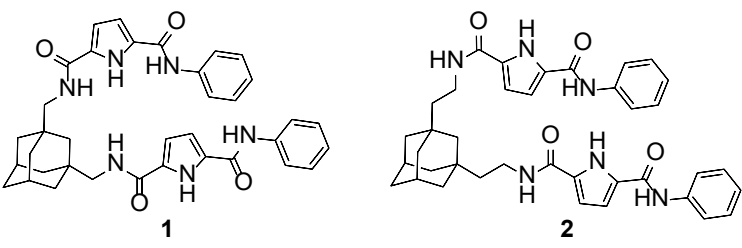

Figure 1. Amidopyrrole receptors 1 and 2.

In this work, the idea was to use two amidopyrrole subunits in a binding site to enhance anion complexation due to additional $\mathrm{H}$-bond donor groups. Unlike our previously prepared receptors containing dipyrromethane subunits, ${ }^{[20 a, c, d]}$ receptors presented herein have a designed cavity for anion capture with a different binding pattern of hydrogen bond donors. It is known that amidopyrroles offer a convergent hydrogen-bonding array, in contrast to the parallel hydrogen-bonding array seen in bipyrroles or urea receptors, and there are numerous examples of various amidopyrrole assemblies in the solid state. ${ }^{[18]}$ In addition, we designed receptors $\mathbf{1}$ and $\mathbf{2}$ (Figure 1) to also establish the effect of extra methylene groups between a rigid spacer and the binding site and to study its influence on the anion-receptor stability constant values. Here we report preparation of new adamantyl amidopyrroles $\mathbf{1}$ and 2, data on their anion binding properties (complexation with $\mathrm{Cl}^{-}, \mathrm{AcO}^{-}$and $\mathrm{H}_{2} \mathrm{PO}_{4}^{-}$), and theoretical analysis of the receptor structure.

\section{EXPERIMENTAL}

${ }^{1} \mathrm{H}$ and ${ }^{13} \mathrm{C}$ NMR spectra were recorded on a Bruker Spectrometer at 300 or $600 \mathrm{MHz}$. All NMR spectra were measured in deuterated solvents using tetramethylsilane as a reference. High resolution mass spectra (HRMS) were measured on an Applied Biosystems 4800 Plus MALDI TOF/TOF instrument. IR spectra were recorded on FT-IR ABB Bonem MB 102 spectrophotometer. The UV/Vis titration experiments were performed on PG instruments limited $\mathrm{T} 80+$ spectrophotometer equipped with a thermostating device. Melting points were obtained using an Original Kofler Mikroheitztisch apparatus (Reichert, Wien) and are uncorrected. Aminoadamantanes $\mathbf{3}^{[23]}$ and $\mathbf{4}^{[23]}$ as well as amidopyrrole derivatives $\mathbf{5}$ and $\mathbf{6}$ were prepared according to the respective literature procedures. ${ }^{[24,25]}$

\section{Synthesis}

1,3-Bis[phenyl-(1H-pyrrole-2,5-dicarboxyamide)]-1,3dimethyladamantane (1)

$\mathrm{N}$-hydroxysuccinimide $(0.13 \mathrm{~g}, 1.13 \mathrm{mmol})$ and $N, N^{\prime}$ dicyclohexylcarbodiimide $(0.23 \mathrm{~g}, 1.1 \mathrm{mmol})$ were added to a solution of pyrrole acid $\mathbf{5}(0.24 \mathrm{~g}, 1 \mathrm{mmol})$ dissolved in $\mathrm{CH}_{2} \mathrm{Cl}_{2}(15 \mathrm{~mL})$ and cooled at $-5{ }^{\circ} \mathrm{C}$. The reaction mixture was stirred at $-5{ }^{\circ} \mathrm{C}$ for 5 hours and left overnight at $4{ }^{\circ} \mathrm{C}$. The crude reaction mixture was evaporated and crude 6 was used in the next step without further purification.

To 1,3-bis(aminomethyl)adamantane (3) $(0.1 \mathrm{~g}, 0.5$ mmol) and $\mathrm{NaHCO}_{3}(0.34 \mathrm{~g}, 4 \mathrm{mmol})$ dissolved in a solvent mixture of THF : $\mathrm{H}_{2} \mathrm{O}=1: 1(18 \mathrm{~mL})$ was added dropwise a solution of activated ester 6 dissolved in THF $(10 \mathrm{~mL})$. The reaction mixture was stirred for 24 hours at room temperature. THF was evaporated and the water layer was extracted with $\mathrm{CH}_{2} \mathrm{Cl}_{2}(2 \times 30 \mathrm{~mL})$. Organic extracts were collected and dried over anhydrous $\mathrm{Na}_{2} \mathrm{SO}_{4}$. After filtration, the solvent was partially evaporated on a rotary evaporator and the solution was stored at $4{ }^{\circ} \mathrm{C}$ overnight. Precipitated white solid was filtered off and the filtrate was evaporated to gain a white solid $(0.32 \mathrm{~g})$. After column chromatography on silica gel using $\mathrm{CHCl}_{3}$ and $\mathrm{MeOH}$ in $\mathrm{CH}_{2} \mathrm{Cl}_{2}(1 \rightarrow 7 \%)$ as eluent, $0.1 \mathrm{~g}$ of product 1 was isolated as a white solid.

1, $32 \%$; white solid, $R_{\mathrm{f}}=0.41\left(5 \% \mathrm{MeOH}\right.$ in $\mathrm{CH}_{2} \mathrm{Cl}_{2}$ ), m.p. above $220^{\circ} \mathrm{C}$; IR (KBr) $\tilde{U}_{\max } / \mathrm{cm}^{-1}: 2360,1652,1384,1097$; ${ }^{1} \mathrm{H}$ NMR (CD $\left.{ }_{3} \mathrm{OD}, 300 \mathrm{MHz}\right) \delta / \mathrm{ppm}: 1.36(\mathrm{~s}, 2 \mathrm{H}), 1.50(\mathrm{~d}, 4 \mathrm{H}$, $J=11.8 \mathrm{~Hz}), 1.55(\mathrm{~d}, 4 \mathrm{H}, J=11.8 \mathrm{~Hz}), 1.66(\mathrm{~s}, 2 \mathrm{H}), 2.08(\mathrm{~s}$, $2 \mathrm{H}), 3.11(\mathrm{~s}, 4 \mathrm{H}), 6.88(\mathrm{~d}, 2 \mathrm{H}, \mathrm{J}=4.0 \mathrm{~Hz}), 7.00-7.04(\mathrm{~m}, 2 \mathrm{H})$, 7.10-7.15 (m, 2H), 7.30-7.36 (m, 4H), 7.63-7.69 (m, 4H); ${ }^{13} \mathrm{C}$ NMR $\left(\mathrm{CD}_{3} \mathrm{OD}, 75 \mathrm{MHz}\right) \delta /$ ppm: $29.9(2 \times \mathrm{CH}), 36.5(2 \times$ C), $37.4\left(4 \times \mathrm{CH}_{2}\right), 40.9\left(\mathrm{CH}_{2}\right), 44.2\left(\mathrm{CH}_{2}\right), 51.7\left(2 \times \mathrm{CH}_{2}\right)$, $113.04(2 \times \mathrm{CH}), 113.3(4 \times \mathrm{CH}), 122.0(4 \times \mathrm{CH}), 125.4(2 \times$ $\mathrm{CH}), 129.8(2 \times \mathrm{CH}), 130.1(2 \times \mathrm{C}), 130.5(4 \times \mathrm{C}), 139.6(2 \times$ C), $163.0(2 \times \mathrm{C})$; HRMS: Anal. Calcd. $\mathrm{C}_{36} \mathrm{H}_{38} \mathrm{~N}_{6} \mathrm{O}_{4}\left([\mathrm{M}]^{+}\right)$ 619.3027, observed: 619.3014

\section{1,3-Bis[phenyl-(1H-pyrrole-2,5-dicarboxyamide]-1,3- diethyladamantane (2)}

To 1,3-bis(aminoethyl)adamantane dihydrochloride $(\mathbf{4} \times 2 \mathrm{HCl})$ $(0.13 \mathrm{~g}, 0.44 \mathrm{mmol})$ and pyrrole acid $5(0.21 \mathrm{~g}, 0.88 \mathrm{mmol})$ dissolved in a solvent mixture of $\mathrm{CH}_{2} \mathrm{Cl}_{2}, \mathrm{CH}_{3} \mathrm{CN}$ and $\mathrm{DMF}$ (10: $10: 3 \mathrm{~mL}$ ) TEA $(0.12 \mathrm{~mL}, 0.88 \mathrm{mmol})$ was added under the nitrogen atmosphere. To the resulted mixture HBTU (0.33 g, $0.88 \mathrm{mmol}$ ) in $\mathrm{CH}_{2} \mathrm{Cl}_{2}(10 \mathrm{~mL}$ ) was added dropwise during 15 minutes and the reaction mixture was subsequently stirred for $46 \mathrm{~h}$ (monitored by TLC, $5 \% \mathrm{MeOH}$ in $\mathrm{CH}_{2} \mathrm{Cl}_{2}$ as eluent). Solvent was evaporated and the saturated aq. solution of $\mathrm{NaCl}(20 \mathrm{~mL})$ was added to the crude reaction mixture. The resulted mixture was extracted two more times using $\mathrm{CH}_{2} \mathrm{Cl}_{2}$ and $\mathrm{Et}_{2} \mathrm{O}$, and the organic extracts were washed with $\mathrm{NaHCO}_{3}$ and water $(20 \mathrm{~mL})$. This led to the formation of emulsion and ethanol was added to separate the organic and the water phase. The organic layer was once washed with citric acid and saturated aq. solution of $\mathrm{NaCl}$. Organic extracts were collected and dried over anhydrous $\mathrm{MgSO}_{4}$. After filtration, the solvent was evaporated on a rotary evaporator and yellow oil ( $0.32 \mathrm{~g})$ 
<smiles>N=CC12CC3CC(C1)CC(CN)(C3)C2</smiles>

$3 n=1$ $4 \times 2 \mathrm{HCl} \mathrm{n}=2$<smiles>O=C(O)c1ccc(C(=O)Nc2ccccc2)[nH]1</smiles>

5

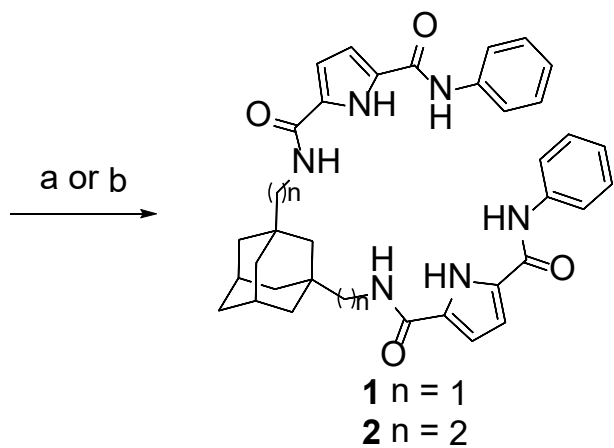

Scheme 1. Synthesis of anion receptors 1 and 2; a) for 1: NHS, DCC, $\mathrm{NaHCO}_{3}, \mathrm{THF} / \mathrm{H}_{2} \mathrm{O}$, b) for 2: $\mathrm{HBTU}, \mathrm{DMF} / \mathrm{CH}_{3} \mathrm{CN} / \mathrm{CH}_{2} \mathrm{Cl}_{2}$.

was obtained. The crude mixture was purified by chromatography on silica gel using $\mathrm{MeOH}$ in $\mathrm{CH}_{2} \mathrm{Cl}_{2}(1 \rightarrow 7$ $\%)$ as eluent. Subsequent preparative chromatography on a silica gel plate using the same eluent furnished $16 \mathrm{mg}$ of product 2 in the form of white crystals.

2, $5 \%$; white solid, $R_{\mathrm{f}}=0.45\left(5 \% \mathrm{MeOH}\right.$ in $\left.\mathrm{CH}_{2} \mathrm{Cl}_{2}\right)$, m.p. $186-192{ }^{\circ} \mathrm{C}$; IR (KBr) $\tilde{U}_{\max } / \mathrm{cm}^{-1}: 2360,1683,1558,1095$; ${ }_{1}^{1} \mathrm{H} \mathrm{NMR}\left(\mathrm{CD}_{3} \mathrm{OD}, 300 \mathrm{MHz}\right) \delta / \mathrm{ppm}: 1.39(\mathrm{~s}, 2 \mathrm{H}), 1.41-1.46$ $(\mathrm{m}, 4 \mathrm{H}), 1.51(\mathrm{~d}, 4 \mathrm{H}, J=12.1 \mathrm{~Hz}), 1.57(\mathrm{~d}, 4 \mathrm{H}, J=12.1 \mathrm{~Hz})$, $1.67(\mathrm{~s}, 2 \mathrm{H}), 2.05(\mathrm{~s}, 2 \mathrm{H}), 3.36-3.41(\mathrm{~m}, 4 \mathrm{H}), 6.83(\mathrm{~d}, 2 \mathrm{H}, J$ $=3.9 \mathrm{~Hz}), 7.00(\mathrm{~d}, 2 \mathrm{H}, J=3.9 \mathrm{~Hz}), 7.10-7.13(\mathrm{~m}, 2 \mathrm{H}), 7.31-$ $7.35(\mathrm{~m}, 4 \mathrm{H}), 7.64-7.68(\mathrm{~m}, 4 \mathrm{H}) ;{ }^{13} \mathrm{C} \mathrm{NMR}\left(\mathrm{CD}_{3} \mathrm{OD}, 75 \mathrm{MHz}\right)$

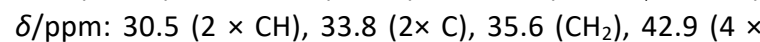
$\left.\mathrm{CH}_{2}\right), 44.3\left(\mathrm{CH}_{2}\right), 112.5(2 \times \mathrm{CH}), 113.4(2 \times \mathrm{CH}), 121.9(2 \times$ $\mathrm{CH}), 125.4(4 \times \mathrm{CH}), 129.8(4 \times \mathrm{CH}), 141.1(2 \times \mathrm{C})$; HRMS: Anal. Calcd. $\mathrm{C}_{38} \mathrm{H}_{42} \mathrm{~N}_{6} \mathrm{O}_{4}\left([\mathrm{M}]^{+}\right)$647.3340, observed: 647.3336 .

\section{Titration Experiments}

The UV/Vis titration experiments were performed on a PG instruments limited $\mathrm{T} 80+$ spectrophotometer at $25^{\circ} \mathrm{C}$. The receptor was dissolved in spectroscopic grade DMSO $(c \approx$ $10^{-5} \mathrm{~mol} \mathrm{dm}^{-3}$ ), in the concentration that corresponds to the maximum of absorbance in the range 0.6-0.9. The solution of the examined receptor was placed in a quartz cuvette $(I=1 \mathrm{~cm}, V=0.9 \mathrm{~mL})$, UV/Vis spectrum was recorded and then small volumes $(5-20 \mu \mathrm{L})$ of the corresponding anion solution were added, altogether between 20-30 additions of anion. DMSO solutions of tetrabutylammonium salts of the anions were used ( $T B A H_{2} P_{4}$, TBAOAc and TBACl), with the concentration range $10^{-4}-10^{-1} \mathrm{~mol} \mathrm{dm}^{-3}$. After each addition of anion aliquot UV/Vis spectra were recorded and the obtained spectrometric data was processed using the Specfit program. ${ }^{[26]}$

\section{Computations}

Conformer search was performed with the Spartan'14 program $^{[27]}$ and selected candidates were then optimized using DFT computations. All geometry optimizations were done with the GAUSSIAN09 program package, ${ }^{[28]}$ using the B3LYP functional[29] augmented by Grimme's D3-dispersion correction $^{[30]}$ in conjunction with the cc-pVDZ basis set. The obtained minima were verified by frequency computations and solvation (DMSO) was accounted for by using the polarizable continuum model (CPCM). ${ }^{[31]}$

\section{RESULTS AND DISCUSSION}

We prepared novel amidopyrroles $\mathbf{1}$ and $\mathbf{2}$ and studied their anion binding affinity. The strategy for synthesis of $\mathbf{1}$ and $\mathbf{2}$ was to prepare the corresponding building blocks, aminoadamantanes and the pyrrole carboxylic acid, followed by amide bond formation between the prepared fragments (Scheme 1). Aminoadamantane derivatives 3 and 4 were obtained from 1,3-adamantanedicarboxylic ${ }^{[32]}$ and 1,3-adamantanediacetic acid, ${ }^{[33]}$ respectively via the corresponding adamantyl cyanides. ${ }^{[34]}$ Synthesis of pyrrole precursors $\mathbf{5}$ and $\mathbf{6}$ is known and very well described in the literature (see Supporting information for more details). ${ }^{[25,35-37]}$

The key reaction step in the synthesis of amidopyrroles $\mathbf{1}$ and $\mathbf{2}$ is formation of the amide bond between the two fragments, the corresponding aminoadamantanes $\mathbf{3}$ or $\mathbf{4}$ and the pyrrole acid $\mathbf{5}$ or its activated ester $\mathbf{6}$. First we employed DCC induced coupling and compound $\mathbf{1}$ was obtained in a moderate yield of $31 \%$. However, difficulties arose with the removal of dicyclohexylurea, a byproduct formed from DCC. Recrystallization and several column chromatographies were needed to obtain a high purity of 1 necessary for titration experiments since the urea byproduct would compete with the prepared receptor in anion complexation. Therefore, we turned our attention to HBTU, another activator used in peptide chemistry. HBTU requires mild reaction conditions; the reaction time is shortened while the yield of the reaction is usually increased. The most important feature, however, is water solubility of the HBTU byproduct, making product 
Table 1. Association constants $(\log \theta \pm \sigma(\log \theta))$ of the complexes of receptors 1 and 2 with anions determined by UV/Vis titrations. ${ }^{(a)}$

\begin{tabular}{|c|c|c|c|c|}
\hline & Receptor & $\mathrm{H}_{2} \mathrm{PO}_{4}^{-}$ & $\mathrm{AcO}^{-}$ & $\mathrm{Cl}^{-}$ \\
\hline & 1 & $3.25 \pm 0.04$ & $\approx 3.50 \pm 0.08$ & $<2^{b}$ \\
\hline & 2 & $3.29 \pm 0.03$ & $\approx 3.40 \pm 0.09$ & $<2^{b}$ \\
\hline \multicolumn{5}{|c|}{$\begin{array}{l}\text { Titrations were performed at } 25^{\circ} \mathrm{C} \text { in a DMSO solution and anions were } \\
\text { added as TBA salts. The complexes were formed in } 1: 1 \text { stoichiometry } \\
\text { giving } 6 / \mathrm{mol}^{-1} \mathrm{dm}^{3} \text {. }\end{array}$} \\
\hline (b) & \multicolumn{4}{|c|}{$\begin{array}{l}\text { Changes in the UV/Vis spectra were small, resulting in difficult fitting and } \\
\text { an estimate of } \log \theta \text { values. }\end{array}$} \\
\hline
\end{tabular}

isolation facile. Unfortunately, repeated chromatographies were still necessary to obtain analytically pure $\mathbf{2}$.

Binding studies of receptors $\mathbf{1}$ and $\mathbf{2}$ were performed with the TBA salts of $\mathrm{Cl}^{-}, \mathrm{AcO}^{-}$and $\mathrm{H}_{2} \mathrm{PO}_{4}^{-}$anions by means of UV/Vis spectrophotometric titration. Acetonitrile would have been the solvent of choice for the planned titrations; however, precipitation of the formed complexes that occurred upon anion addition prevented its use. To determine reliable concentrations of species present in equilibrium, we turned to DMSO that is more polar, but unfortunately is also highly competitive in the binding process. Dependencies of the UV/Vis spectra on anion concentrations were processed by multivariate non-linear regression analysis using the Specfit program. ${ }^{[26]}$ Determined complex stoichiometries and stability constants are presented in Table 1 and an illustrative example of a titration course is depicted in Figure 2.

Compounds 1 and $\mathbf{2}$ dissolved in DMSO ( $c=10^{-5} \mathrm{~mol}$ $\mathrm{dm}^{-3}$ ) show clear absorption spectra in the $270-340 \mathrm{~nm}$ region. Addition of TBA salts to the DMSO solution of receptors induced moderate spectral changes in case of $\mathrm{H}_{2} \mathrm{PO}_{4}^{-}$, while addition of $\mathrm{AcO}^{-}$and $\mathrm{Cl}^{-}$had a small impact on the appearance of the spectra. Furthermore, small spectral changes in case of $\mathrm{AcO}^{-}$and $\mathrm{Cl}^{-}$prevented us from determining complexation stability constants with high precision (Figures S1-S5). This is especially apparent for $\mathrm{Cl}^{-}$ where fitting was rather difficult and the calculated stability constant is inaccurate ( $\log \beta$ values were estimated to be $<$ 2). Addition of $\mathrm{H}_{2} \mathrm{PO}_{4}^{-}$to the DMSO solution of 1 resulted in a decrease of absorbance at $295 \mathrm{~nm}$ (Figure 2). Formation of isosbestic point at $310 \mathrm{~nm}$ indicates a presence of two colored species in equilibrium, i.e., the formed complex and free receptor 1 .

After considering the results obtained by UV/Vis study and by fitting experimental data to a $1: 1$ stoichiometry model, we determined that more stable complexes are formed with more basic anions, regardless of their differing geometry. Since all studied complexes follow a 1 : 1 stoichiometry, we concluded that anion binding is accomplished only on one side of the receptor. Although our intention was to design receptors with two active side

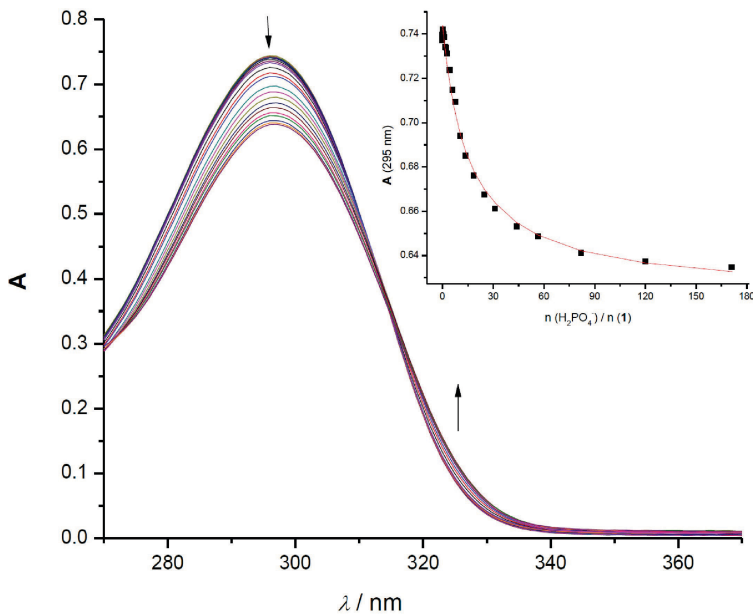

Figure 2. UV/Vis titration spectra of the DMSO solution of 1 ( $c=4.5 \times 10^{-5} \mathrm{~mol} \mathrm{dm}^{-3}$ ) upon addition of $\mathrm{H}_{2} \mathrm{PO}_{4}{ }^{-}$anion. The spectra were corrected for dilution. Inset: absorbance of the DMSO solution of 1 at $300 \mathrm{~nm}$ vs. mole ratio of $\mathrm{H}_{2} \mathrm{PO}_{4}^{-} / 1$ (- exp. values, - calcd. values).

arms that would form a central cavity suitable for anion placement, such binding site cooperation appears to be energetically unfavorable and does not occur in a polar DMSO solution. Since DMSO is an electron donor and an acceptor of hydrogen bonds, it comes as no surprise that it competes strongly for the anion and diminishes complexation capabilities of receptors $\mathbf{1}$ and $\mathbf{2}$. In accordance with this, the observed values of the equilibrium constants are lower than expected when accounting for the number of possible binding sites.

In order to gain more insight into the noncooperative behavior of receptor side arms during the complexation process in a polar solution, we also conducted theoretical studies on compound 1. Note that both receptors $\mathbf{1}$ and $\mathbf{2}$, despite being in principle directed by a rigid adamantane backbone, still possess a significant degree of freedom when considering their side arm flexibility. As a result, one can expect a large number of conformers to be present in a solution. Indeed, conformational analysis of even somewhat less flexible compound 1 yielded a large dataset since, as explained, the side chains present in the structure can adopt a wide range of orientations. That is why we focused our attention only on selected stable conformers of 1 that can feasibly engage in binding interactions with anions in order to shed some more light on the obtained $1: 1$ stoichiometry. We chose conformers for DFT computation based on criteria of $\mathrm{NH}$ group directionality, i.e., by distinguishing whether all $\mathrm{H}$ atoms bound to nitrogen atoms point towards the same or opposite direction of the amidopyrrole moiety (Figure 3). This gives structures with an alternating $\mathrm{NH}$ pattern, where 

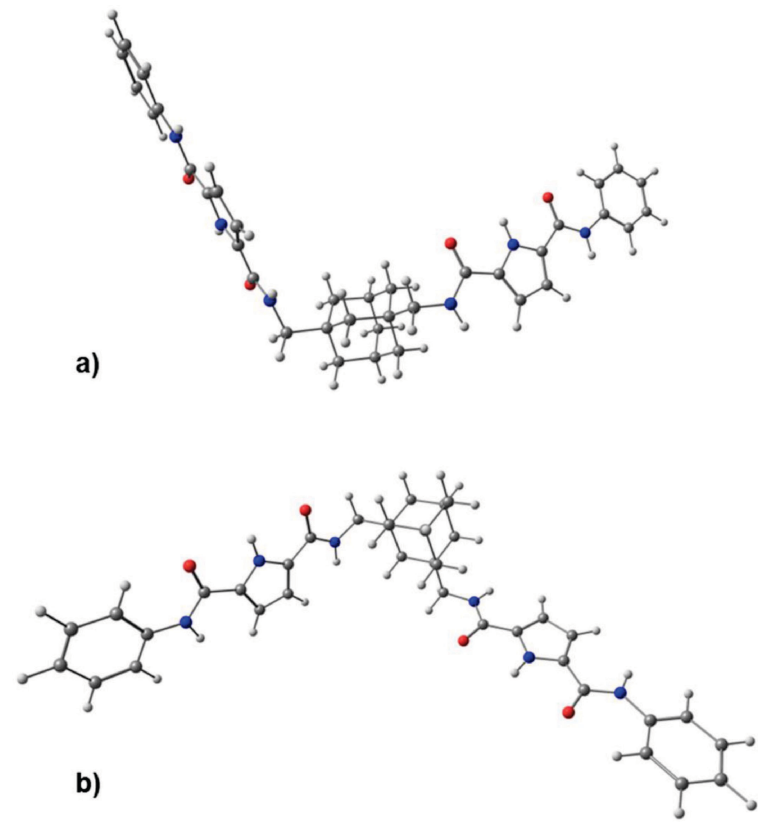

Figure 3. The most stable conformer ( $\mathrm{C} 2$ ) of receptor 1 in the computed series, a) side view, b) top view.

the pyrrole $\mathrm{H}$ is pointing in opposite direction with regard to the two amide $\mathrm{H}$ atoms; and with equally oriented $\mathrm{NH}$ pattern, where all three $\mathrm{H}$ atoms form a concave amidopyrrole substructure. The two described directionality types are in connection with the binding ability of the receptor since one would expect that the concave shape is more likely to engage in anion binding due to more opportunities for directed hydrogen bond formation.

When comparing the five computed conformers of $\mathbf{1}$, one notices that the most stable conformer is $\mathbf{C 2}$, closely followed by $\mathbf{C 1}$ (Table 2, Figure S6). Both have the alternating $\mathrm{NH}$ pattern and the two side chains are not in close contact with each other. C1 is completely spread out and has a Cs symmetry while in $\mathbf{C 2}$ one side arm is a bit tilted. It is obvious that the rigid adamantane backbone cannot completely enforce side arm stiffness and the methylene groups connecting the polycyclic framework with amidopyrrole units indeed control the subtle conformational differences. The overall preference for an alternating pattern comes as no surprise since the $\mathrm{NH}$ groups can be easily stabilized with the DMSO solvent molecules and, moreover, the structures of $\mathbf{C 1}$ and $\mathbf{C 2}$ are quite unhindered and consequently energetically favorable.

Conformers C3 and C4 adopt the pattern of equally oriented $\mathrm{NH}$ groups of amidopyrrole subunits, making them more likely candidates for stronger anion binding.
Table 2. Relative energies, $\Delta G(298 \mathrm{~K})$, of selected conformers for receptor 1 computed at the B3LYP-D3/cCpVDZ level of theory in DMSO using the polarizable continuum model (CPCM)

\begin{tabular}{cc}
\hline Conformer & $\Delta G(298 \mathrm{~K}) / \mathrm{kcal} \mathrm{mol}^{-1}$ \\
\hline C1 & 0.8 \\
C2 & 0.0 \\
C3 & 12.2 \\
C4 & 6.4 \\
C5 & 18.3 \\
\hline
\end{tabular}

Unfortunately, when compared to $\mathbf{C 1}$ and $\mathbf{C 2}$, it becomes apparent that such amidopyrrole orientation is not necessarily the most stable in terms of intramolecular interactions. Bending of amidopyrrole side arms can lead to a very crowded central area of the molecule, as is the case for conformer $\mathbf{C 4}$. Although interactions between benzene rings somewhat alleviate the crowding and stabilize the structure, which is reflected in the relative energy value for C4 (Table 2, Figure S6), the resulting cavity is nevertheless unsuitable for feasible anion accommodation and side arm cooperativity during binding. Important to note is the energetic difference between $\mathbf{C 3}$ and $\mathbf{C 1}$ or C2. These conformers are all spread out, with no significant interaction between the side arms, but conformer $\mathbf{C} 3$ with concave amidopyrroles is markedly less stable that the other two with an alternating $\mathrm{NH}$ pattern. It therefore appears that conformers of receptor $\mathbf{1}$ with amidopyrrole orientation more suitable for anion binding (concave pattern) are less stable in a DMSO solution than their alternating analogues, which is also in agreement with the observed lower values of equilibrium constants.

Conformer C5 is the least stable structure in the studied series, with an amidopyrrole pattern different from the two described until now. Both of its side arms have one amido $\mathrm{NH}$ group (the one nearer to the adamantane backbone) pointing in opposite direction when compared to the pyrrole and the remaining amido $\mathrm{NH}$ group. Such orientation is highly unfavorable but also does not contribute to the coordinated side arm binding event so we did not pursue such type of conformers any further.

Noteworthy is that more effective stabilization of structures with spread out side arms agrees well with the experimental observation of a $1: 1$ stoichiometry binding model with anions, meaning that cooperation between amidopyrroles upon binding is unlikely due to overcrowding and only a single side arm interacts with the anion. The observed lower constant values reflect a failure of stable central cavity formation and the receptor consequently behaves as if it had only one binding subunit instead of the two it actually possesses. 


\section{CONCLUSION}

In summary, we prepared amidopyrroles $\mathbf{1}$ and $\mathbf{2}$, novel adamantane-containing anion receptors, and examined their binding with anions $\left(\mathrm{Cl}^{-}, \mathrm{AcO}^{-}\right.$and $\left.\mathrm{H}_{2} \mathrm{PO}_{4}^{-}\right)$using UV/Vis spectroscopy. We showed that receptors $\mathbf{1}$ and $\mathbf{2}$ form complexes with a $1: 1$ stoichiometry and that their affinity for oxo-anions is more pronounced than for the chloride. Such affinity is most likely due to the formation of multiple hydrogen interactions with the anion, meaning that oxo-anions benefit more from the formed hydrogen bond network on accounts of their higher basicity, and regardless of their individual geometry. Experimentally observed binding behavior and the 1: 1 stoichiometry binding mode was further confirmed and rationalized using DFT computations. Although cooperativity between amidopyrrole side arms does not take place during the binding event, we could nevertheless show that the prepared receptors still engage in anion complexation, albeit with only one amidopyrrole subunit.

Acknowledgment. We thank the Ministry of Science, Education and Sports of the Republic of Croatia for financial support (grant no. 098-0982933-2911).

Supplementary Information. Supporting information to the paper is attached to the electronic version of the article at: http://doi.org/10.5562/cca3248.

\section{REFERENCES}

[1] a) A. Bianchi, K. Bowman-James, E. García-España, Supramolecular Chemistry of Anions, Wiley-VCH: New York, NY, 1997; b) J. L. Sessler, P. A. Gale, W.-S. Cho, Anion Receptor Chemistry, RSC, Cambridge, 2006; c) J. W. Steed, J. L. Atwood, Supramolecular Chemistry, Wiley-VCH, New York, NY, 2009.

[2] V. Amendola, D. Esteban-Gomez, L. Fabbrizzi, M. Licchelli, Acc. Chem. Res. 2006, 39, 343.

[3] A. Brown, P. D. Beer, Chem. Commun. 2016, 52, 8645.

[4] B. L. Schottel, H. T. Chifotides, K. R. Dunbar, Chem. Soc. Rev. 2008, 37, 68.

[5] a) S. Kubik, Chem. Soc. Rev. 2010, 39, 3648; b) M. J. Langton, C. J. Serpell, P. Beer, Angew. Chem. Int. Ed. 2016, 55, 1974.

[6] a) C. Caltagirone, P. A. Gale, Chem. Soc. Rev. 2009, 38, 520; b) P. A. Gale, Chem. Soc. Rev. 2010, 39 3746; c) P. A. Gale, Chem. Commun. 2011, 47, 82. d) M. Wenzel, J. R. Hiscock, P. A. Gale, Chem. Soc. Rev. 2012, 41, 480; e) P. A. Gale, N. Busschaert, C. J. E. Haynes, L. E. Karagiannidis, I. L. Kirby, Chem. Soc. Rev. 2014, 43, 205; f) P. A. Gale, C. Caltagirone,
Chem. Soc. Rev. 2015, 44, 4212; g) P. A. Gale, E. N. W. Howe, X. Wu, Chem. 2016, 1, 351; h) P. Molina, F. Zapata, A. Caballero, Chem. Rev. 2017, 117, 9907.

[7] N. Busschaert, C. Caltagirone, W. Van Rossom, P. A. Gale, Chem. Rev. 2015, 115, 8038.

[8] a) A. Rajbanshi, B. A. Moyer, R. Custelcean, Crys. Growth Des. 2011, 11, 2702; b) N. Gimeno, R. Vilar, Coord. Chem. Rev. 2006, 250, 3161.

[9] a) R. Vilar, Angew. Chem. Int. Ed. 2003, 42, 1460; b) M. W. Hosseini, Coord. Chem. Rev. 2003, 240, 157; c) M. D. Lankshear, P. D. Beer, Coord. Chem. Rev. 2006, 250, 3142; d) N. Gimeno, R. Vilar, Coord. Chem. Rev. 2006, 250, 3161; e) F. P. Schmidtchen, Coord. Chem. Rev. 2006, 250, 2918.

[10] a) A. P. de Silva, H. Q. N. Gunaratne, T. Gunnlaugsson, A. J. M. Huxley, C. P. McCoy, J. T. Rademacher, T. E. Rice, Chem. Rev. 1997, 97, 1515; b) P. D. Beer, P. A. Gale, Angew. Chem. Int. Ed. 2001, 40, 486; c) R. Martínez-Máñez, F. Sancenón, Chem. Rev. 2003, 103, 4419; d) T. Gunnlaugsson, M. Glynn, G. M. Tocci, P. E. Kruger, F. M. Pfeffer, Coord. Chem. Rev. 2006, 250, 3094; e) R. M. Duke, E. B. Veale, F. M. Pfeffer, P. E. Kruger, T. Gunnlaugsson, Chem. Soc. Rev. 2010, 39, 3936; f) L. E. Santos-Figueroa, M. E. Moragues, E. Climent, A. Agostini, R. Martínez-Máñez, F. Sancenón, Chem. Soc. Rev. 2013, 42, 3489.

[11] Z. Zhang, P. R. Schreiner, Chem. Soc. Rev. 2009, 38, 1187.

[12] a) J. T. Davis, O. Okunola, R. Quesada, Chem. Soc. Rev. 2010, 39, 3843; b) P. A. Gale, Acc. Chem. Res. 2011, 44, 216.

[13] F. Pina, M. A. Bernardo, E. Garcia-Espana, Eur. J. Inorg. Chem. 2000, 10, 2143.

[14] a) C. R. Bondy, S. J. Loeb, Coord. Chem. Rev. 2003, 240, 77; b) S. O. Kang, R. A. Begum, K. BowmanJames, Angew. Chem. Int. Ed. 2006, 45, 7882; c) R. B. P. Elmes, K. A. Jolliffe, Chem. Commun. 2015, 51, 4951.

[15] a) V. Amendola, D. Esteban-Gomez, L. Fabbrizzi, M. Licchelli, Acc. Chem. Res. 2006, 39, 343; b) V. Amendola, L. Fabbrizzi, L. Mosca, Chem. Soc. Rev. 2010, 39, 3889; c) V. Blažek Bregović, N. Basarić, K. Mlinarić-Majerski, Coord. Chem. Rev. 2015, 295, 80.

[16] a) J. L. Sessler, S. Camiolo, P. A. Gale, Coord. Chem. Rev. 2003, 240, 17; b) H. Maeda, Eur. J. Org. Chem. 2007, 32, 5313; c) S. K. Kim, J. L. Sessler, Acc. Chem. Res. 2014, 47, 2525; d) D. S. Kim, J. L. Sessler, Chem. Soc. Rev. 2015, 44, 532; e) Vargas-Zuniga, G. I. J. L. Sessler, Coord. Chem. Rev. 2017, 345, 281.

[17] a) S. J. Brooks, P. A. Gale, Macrocyclic Chemistry 2005, 153; b) P. Dydio, D. Lichosyt, J. Jurczak, Chem. Soc. Rev. 2011, 40, 2971. 
[18] a) P. A. Gale, S. Camiolo, C. P. Chapman, M. E. Light, M. B. Hursthouse, Tetrahedron Lett. 2001, 42, 5095; b) P. A. Gale, S. Camiolo, G. J. Tizzard, C. P. Chapman, M. E. Light, S. J. Coles, M. B. J. Hursthouse, Org. Chem. 2001, 66, 7849; c) K. Navakhun, P. A. Gale, S. Camiolo, M. E. Light, M. B. Hursthouse, Chem. Commun. 2002, 2084; d) I. E. D. Vega, S. Camiolo, P. A. Gale, M. B. Hursthouse, M. E. Light, Chem. Commun. 2003, 1686; e) P. A. Gale, Chem. Commun. 2005, 3761; f) J. L. Sessler, G. D. Pantos, P. A. Gale, M. E. Light, Org. Lett. 2006, 8, 1593; g) P. A. Gale, Acc. Chem. Res. 2006, 39, 465; h) I. E. D. Vega, P. A. Gale, M. B. Hursthouse, M. E. Light, Org. Biomol. Chem. 2004, 2, 2935.

[19] a) C. Schmuck, J. Lex, Org. Lett. 1999, 1, 1779; b) C. Schmuck, Chem. Commun. 1999, 843; c) C. Schmuck, V. Bickert, Org. Lett. 2003, 24, 4597; d) C. Schmuck, M. Heil, ChemBioChem. 2003, 4, 1232; e) C. Schmuck, V. Bickert, Org. Lett. 2003, 5, 4579; f) C. Schmuck, L. Geiger, J. Am. Chem. Soc. 2004, 126, 8898; g) C. Schmuck, J. Dudaczek, Tetrahedron Lett. 2005, 46, 7101; h) C. Schmuck, L. Geiger, J. Am. Chem. Soc. 2005, 127, 10486; i) C. Schmuck, M. Schwegmann, J. Am. Chem. Soc. 2005, 127, 3373.

[20] a) M. Renić, N. Basarić, K. Mlinarić-Majerski, Tetrahedron Lett. 2007, 48, 7873; b) M. Alešković, I. Halasz, N. Basarić, K. Mlinarić-Majerski, Tetrahedron 2009, 65, 2051; c) M. Alešković, N. Basarić, K. Mlinarić-Majerski, K. Molčanov, B. Kojić-Prodić, M. K. Kesharwani, B. Ganguly, Tetrahedron 2010, 66, 1689; d) M. Alešković, N. Basarić, I. Halasz, X. Liang, W. Qin, K. Mlinarić-Majerski, Tetrahedron 2013, 69, 1725.

[21] a) V. Blažek, N. Bregović, K. Mlinarić-Majerski, N. Basarić, Tetrahedron 2011, 67, 3846; b) V. Blažek, K. Molčanov, K. Mlinarić-Majerski, B. Kojić-Prodić, N. Basarić, Tetrahedron 2013, 69, 517; c) V. Blažek Bregović, I. Halasz, N. Basarić, K. Mlinarić-Majerski, Tetrahedron 2015, 71, 9321.
[22] M. Šekutor, K. Mlinarić-Majerski, Tetrahedron Lett. 2014, 55, 6665.

[23] K. Aigami, Y. Inamoto, N. Takaishi, K. Hattori, A. Takatsuki, G. Tamura J. Med. Chem. 1975, 18, 713.

[24] L. Hernandez-Folgado, D. Baretić, I. Piantanida, M. Marjanović, M. Kralj, T. Rehm, C. Schmuck, Chem. Eur. J. 2010, 16, 3036.

[25] R. Kumar, J. W. Lown, Org. Biomol. Chem. 2003, 1, 2630.

[26] a) H. Grampp, M. Maeder, C. J. Meyer, A. D. Zuberbühler, Talanta 1985, 32, 95; b) H. Grampp, M. Maeder, C. J. Meyer, A. D. Zuberbühler, Talanta 1985, 32, 257; c) H. Grampp, M. Maeder, C. J. Meyer, A. D. Zuberbühler, Talanta 1985, 32, 1133.

[27] Spartan'14 Wavefunction, Inc. Irvine, CA.

[28] M. J. Frisch et al. Gaussian 09, Gaussian, Inc., Wallingford, CT, USA, 2013.

[29] a) A. D. Becke, J. Chem. Phys. 1993, 98, 5648-5652; b) C. Lee, W. Yang, R. G. Parr, Phys. Rev. B 1988, 37, 785.

[30] S. Grimme, J. Antony, S. Ehrlich, H. Krieg, J. Chem. Phys. 2010, 132, 154104.

[31] a) V. Barone, M. Cossi, J. Phys. Chem. A, 1998, 102, 1995; b) M. Cossi, N. Rega, G. Scalmani, V. Barone, J. Comp. Chem. 2003, 24, 669.

[32] H. Stetter, C. Wulff, Chem. Ber. 1960, 93, 1366.

[33] K. Bott, Chem. Ber. 1968, 101, 564.

[34] K. Mlinarić-Majerski, R. Margeta, J. Veljković, Synlett, 2005, 13, 2089.

[35] D. M. Bailey, R. E. Johnson, N. F. Albertson, Org. Syn. 1988, 6, 618

[36] a) R. M. Silverstein, E. E. Ryskiewicz, C. Willard, Org. Syn. 1956, 36, 74; b) R. M. Silverstein, E. E. Ryskiewicz, C. Willard, Org. Syn. 1963, 4, 831.

[37] G. Marth, R. J. Anderson, B. G. Thompson, M. Ashton, P. W. Groundwater, Tetrahedron 2010, 66, 6113. 